\title{
SODIUM TRANSPORT ACROSS THE SURFACE MEMBRANE OF RED BLOOD CELLS IN HEREDITARY SPHEROCYTOSIS ${ }^{1}$
}

\author{
BY JOHN F. BERTLES 2 \\ (From the Department of Medicine, The University of Rochester School of Medicine and \\ Dentistry, and the Medical Service of the Strong Memorial Hospital, \\ Rochester, $N . Y$.)
}

(Submitted for publication September 20, 1956; accepted February 21, 1957)

The erythrocyte of hereditary spherocytosis (HS), compared with the normal human erythrocyte, is characterized by an increased thickness: diameter ratio, a greater tendency to hemolyze in hypotonic solutions of sodium chloride (osmotic fragility), and a higher rate of hemolysis when incubated at body temperature (spontaneous autohemolysis) (1). Evidence of abnormalities in the glycolytic cycle of the HS cell has recently been presented (2) and corroborated (3). The in vitro movement of sodium ion $(\mathrm{Na})$ across the surface membrane of washed erythrocytes from one patient with HS has been quantitated (4): the rate of extrusion was abnormally high both before and after splenectomy. A normally functioning glycolytic cycle has become an experimentally well established requisite for normal cation transport ${ }^{3}$ across the surface membrane of erythrocytes (6). Cation transport is required to maintain the low $\mathrm{Na}$ and high potassium $(\mathrm{K})$ concentrations in human red cells, as they contrast to plasma $\mathrm{Na}$ and $\mathrm{K}$ concentrations. Consequently this study was planned to determine:

1) whether HS red cells demonstrate in vitro $\mathrm{Na}$ transport rates that vary from normal to the same degree for each patient; and

1 This study was aided by a grant (Contract DA-49007-MD 632) from the Department of the Army, Office of the Surgeon General.

2 Postdoctorate Research Fellow, U. S. Public Health Service. Present address: Department of Medicine, Massachusetts General Hospital, Boston, Mass.

8 "Transport" has been defined as movement against a gradient, implying "the use of an energy supply other than, or additional to, thermal agitation" (5). Since it remains to be shown precisely how energy from glycolysis relates to cation carrier mechanisms, in this paper the more general application of the term "transport" is used: movement against gradients of concentration and electrochemical potential. "Transfer" indicates movement in any direction.
2) how the variation from normal relates to other characteristics of $\mathrm{HS}$ cells.

Studies on a total of 14 individuals are presented: Cases 1 through 10 are splenectomized patients, with complete hematologic recovery by routine testing (hemoglobin, hematocrit, and reticulocyte count), whose erythrocytes continue to demonstrate the characteristics of HS. Cases $\mathrm{A}$ and $\mathrm{B}$ are hematologically normal controls; duplicate $\mathrm{Na}$ transport studies were done on their red cells to determine reproducibility. Cases C and $\mathrm{D}$ are hematologically normal controls splenectomized in the past for traumatic splenic rupture and idiopathic thrombocytopenic purpura, respectively.

$\mathrm{Na}$ transport measurements were done on red cells from all cases presented. Determinations of osmotic fragility and rate of autohemolysis were done on all cases except $C$ and $D$, and were performed on the same day as the transport study unless otherwise noted in Table I. Correlations were sought among the values for rate of $\mathrm{Na}$ transport, osmotic fragility, and rate of autohemolysis.

\section{METHODS}

Design of system for in vitro measurement of rate of $\mathrm{Na}$ transport. Related experimental schemes have been described by Sheppard and Martin (7), Raker, Taylor, Weller, and Hastings (8), Harris and Maizels (9), Solomon (10), and Love and Burch (11). The method used in this study was a composite, striving for minimal cell manipulation prior to addition of isotope. In each case, $40 \mathrm{ml}$. of venous blood were drawn through a No. 18 needle into a $50-\mathrm{ml}$. syringe containing $8 \mathrm{mg}$. heparin sodium in 0.8 $\mathrm{ml}$. of isotonic sodium chloride solution. The subjects were under no dietary restrictions. Blood was transferred immediately to a siliconed $250-\mathrm{ml}$. Erlenmeyer flask containing $100 \mathrm{mg}$. glucose (more than sufficient to maintain an adequate concentration of glucose in the blood in the presence of leukocytes throughout the experiment [12]). The flask was immediately fixed to a shaker platform enclosed in an air incubator with temperature controlled to $37.5 \pm 0.5^{\circ} \mathrm{C}$. Agitation of the system was horizontal 


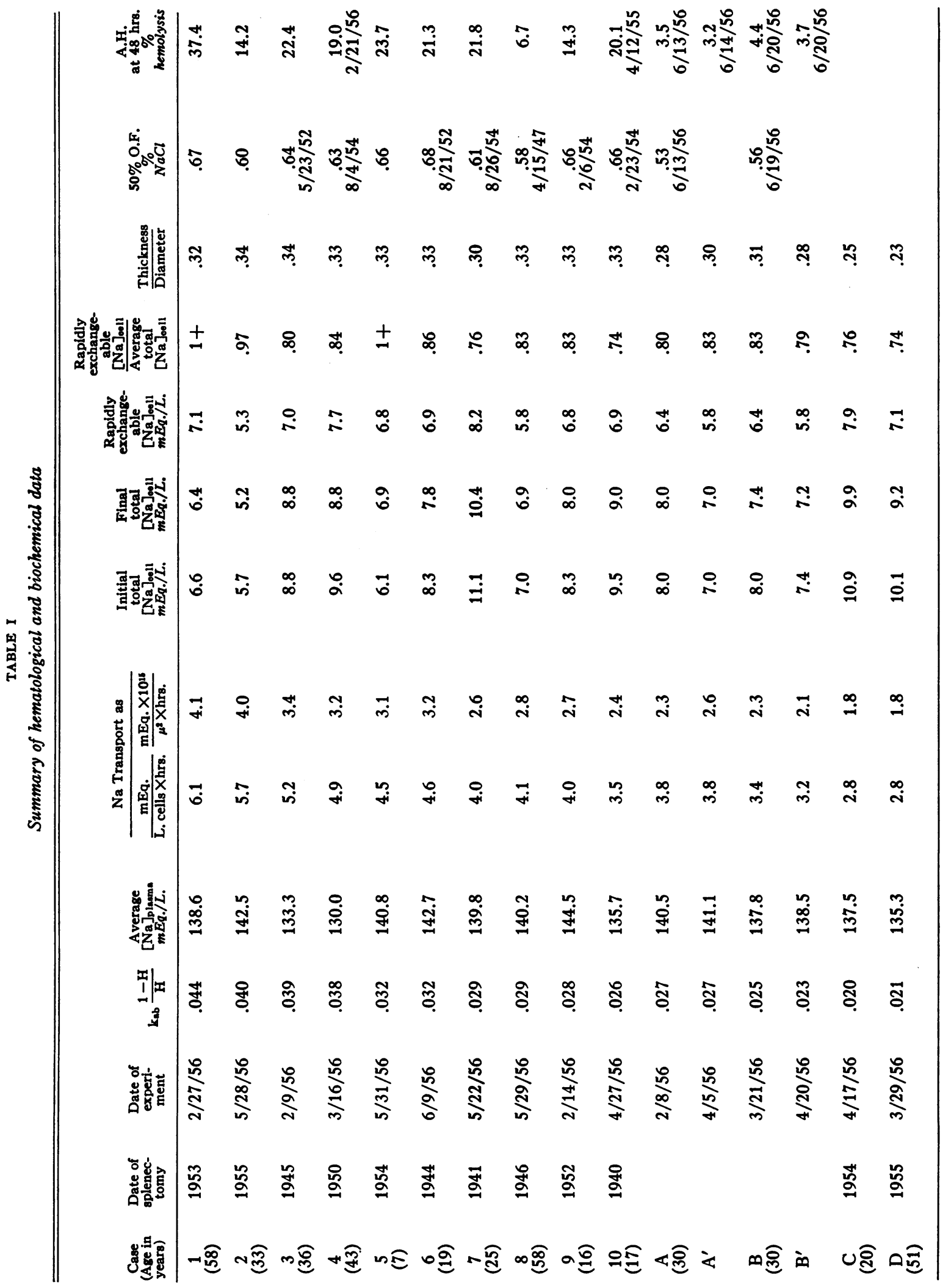


at 150 strokes per minute over a $2-\mathrm{cm}$. traverse. A constant atmosphere of 5 per cent $\mathrm{CO}_{2}$ and 95 per cent $\mathrm{O}_{2}$ was maintained in the flask. When constant $\mathrm{pH}^{4}$ was reached, approximately 0.3 microcurie of $\mathrm{Na}^{206}$ contained in $0.4 \mathrm{ml}$. of isotonic sodium chloride solution was added to the blood, the flask was returned to the shaker, and the experiment timed from the moment of addition of isotope.

Sampling. About $4.5 \mathrm{ml}$. of whole blood for determinations of cell and plasma radioactivity and total $\mathrm{Na}\left(\mathrm{Na}^{\mathrm{2}}+\right.$ $\mathrm{Na}^{23}$ ) concentrations were pipetted from the flask at 12 minutes and at hourly intervals thereafter until the concentration of radioactivity in the cell fraction reached a plateau (Figure 1). Duration of experiments ranged from 6 to 7 hours, with plateau generally not being reached until after 5 hours. Duplicate microhematocrit (13) determinations were done on each sample, and then duplicate aliquots of whole blood were immediately pipetted into 10 by $60 \mathrm{~mm}$. glass tubes with a pipette recalibrated to deliver $2.00 \mathrm{ml}$. of blood. The aliquots were centrifuged at 1,710 R. C. F. for $30 \mathrm{~min}$., following which the supernatant plasmas were pipetted off and combined for subsequent measurements of total $\mathrm{Na}$ and of radioactivity. The surface of each packed cell mass, plus the tube interior above the surface, were carefully washed free of plasma with four changes of isosmotic (approximately 5.2 per cent) glucose solution, using a Pasteur pipette and exercising great care not to disturb the red cell mass. The subsequent determination of radioactivity remaining in the packed cell mass was not significantly altered when three to six such changes of wash solution were employed. Four changes were arbitrarily chosen.

Radioactivity determinations. Duplicate $0.5-\mathrm{ml}$. aliquots of plasma and the duplicate aliquots of packed cells were counted at constant volume in a well-type scintillation counter to within 1 per cent probable error. In more than 100 sets of duplicate packed cell counts, all but 3 duplicates agreed within 2 per cent, and those 3 agreed within 5 per cent.

Corrections for trapped plasma. Using $\mathrm{I}^{131}$ human serum albumin as a plasma tracer, we confirmed the finding (14) that the volume of plasma trapped among HS cells spun at $10,000 \mathrm{RPM}$ in a capillary tube (13) is about 2.5 times that trapped with normal cells. The true value of hematocrit, ${ }^{6}$ within the error of the method and within the hematocrit range of this study (from 36 to 46 per cent),

4 Beckman model G glass electrode pH meter, open cup. Readings by this method are slightly higher than those obtained in a closed system. True $\mathrm{pH}$ of 7.6 was not exceeded (9). $\mathrm{pH}$ dropped about 0.2 unit during each experiment.

Identity and purity of the radioactive isotope were confirmed through the courtesy of H. Mermagen and D. H. Maillie, Atomic Energy Project, University of Rochester.

"The term "hematocrit" is used by some authors to indicate the calibrated tube in which blood is centrifuged in order to determine the fractional volume of blood occupied by red cells. "Hematocrit" in general clinical usage means this fraction expressed as per cent, and this meaning is intended in this paper. may be obtained by subtracting 1 from the capillary hematocrit reading for normal cells, and subtracting 2.5 from the reading for $\mathrm{HS}$ cells. In similar fashion the corrections for plasma trapped in the packed cell mass in 10 by $60 \mathrm{~mm}$. tubes under the conditions of the experiment were obtained : $0.032 \mathrm{ml}$. plasma per $\mathrm{ml}$. normal cells, and 0.038 ml. plasma per ml. HS cells. These corrections were applied when calculating counts per minute (CPM) per $\mathrm{ml}$. cells, and when determining total $\mathrm{Na}$ concentrations of cells and mean corpuscular volume (MCV).

Total $\mathrm{Na}\left(\mathrm{Na}^{\mathrm{2}}+\mathrm{Na}^{23}\right)$ determinations. A flame photometer (lithium internal standard) of the type described by Berry, Chappell, and Barnes (15) was used. Aliquots of plasma were diluted 1:500, and the packed cell masses after counting were diluted to $100 \mathrm{ml}$. The feasibility of employing red cell hemolysate for flame photometry is recognized (16-18). Small downward corrections of cell $\mathrm{Na}$ values in the presence of $\mathrm{K}$ were required. The agreement between determinations of cell $\mathrm{Na}$ concentration done on the duplicate aliquots was, to 2 standard deviations (2 S.D.), within $0.3 \mathrm{mEq}$. per L. cells. Variability of plasma $\mathrm{Na}$ concentration over the course of each experiment was never over 2.5 per cent, and was generally much less.

Hemolysis during Na transport experiments. Determined as oxyhemoglobin, this was slightly over 0.5 per cent of the cell mass in four instances. The per cent hemolysis bore no constant relation to cell $\mathrm{Na}$ transport rate.

$\mathrm{Na}$ transport rate calculations for red cells. Solomon's notation (10) is employed. Let the movement of isotope be described:

$$
\frac{d q}{d t}=k_{a b} p \frac{v_{p}}{v_{q}}-k_{b a} q \frac{v_{p}}{v_{q}}
$$

where $q=\left[\mathrm{Na}^{22}\right]_{\text {ello }}$ and $\mathrm{p}=\left[\mathrm{Na}^{22}\right]$

$\mathrm{t}=$ time

$\mathrm{v}_{\mathrm{q}}=$ cell mass volume $=\mathrm{H}=$ hematocrit

$\mathrm{v}_{\mathrm{p}}=$ plasma volume $=1-\mathrm{H}$.

Letting $\mathrm{q}_{\infty}=\left[\mathrm{Na}^{22}\right]_{\text {cells }}$ at plateau, the plot of $\ln \left(1-\frac{\mathrm{q}}{\mathrm{q}_{\infty}}\right)$ against time (Figure 2), thus minimizing errors involved in single determinations of $\mathrm{q}$, should yield a straight line if the assumptions leading to construction of Equation 1 are correct. If slope equals $T$, then :

$$
\mathrm{k}_{\mathrm{ab}} \frac{1-\mathrm{H}}{\mathrm{H}}=\frac{-\mathrm{Tq}_{\infty}}{\mathrm{p}_{0}}
$$

where $\mathrm{p}_{0}=\left[\mathrm{Na}^{22}\right]_{\text {plasma }}$ at time zero.

$\mathrm{k}_{\mathrm{ab}} \frac{1-\mathrm{H}}{\mathrm{H}}$ represents the fraction of the total $\mathrm{Na}$ concentration of plasma $\left(\mathrm{Na}^{20}+\mathrm{Na}^{23}\right)$ which transfers into one liter of cells in 1 hour. If a steady state obtains, this is also the quantity of $\mathrm{Na}$ transported out of 1 liter of cells per hour.

p drops less than 4 per cent during the course of an experiment, and since $p_{0}$ is a critical value in computing $k_{\mathrm{ab}}$, we have employed the average value of $p$ during each experiment to represent $p_{0}$. We have also used average $p$ instead of $p_{\infty}$ in the calculation of "rapidly exchangeable" 
cell $\mathrm{Na}(10)$ :

$$
[\mathrm{Na}]_{\text {exch. }}=\frac{\mathrm{q}_{\infty}}{\mathrm{p}_{\infty} /[\mathrm{Na}]_{\text {plesma }}}
$$

where $p_{\infty}=\left[\mathrm{Na}^{22}\right]_{\text {plasms }}$ at plateau.

It must be pointed out that cell $\mathrm{Na}$ concentration dropped slightly over the course of most of the experiments (see Table I). This is a recognized phenomenon (9-11) and detracts from the accuracy of the transport calculations, but does not invalidate them.

Expression of transport rate in terms of surface area of cells rather than volume of cells. Movement of $\mathrm{Na}$ across the red cell membrane in terms of cell surface area may permit a more valid comparison of one cell type with another when area:volume ratios differ (9). Convenient rather than highly accurate devices were employed in this conversion. We used Emmons' formula (19) for cell surface area, which assumes the cell is a truncated cylinder:

$$
\text { Area }=2 \pi r(r+h)
$$

where $\mathrm{r}=$ cell transverse diameter $/ 2$

$$
\mathrm{h}=\text { cell thickness }=\mathrm{MCV} / \pi^{2} \text {. }
$$

It is assumed that the error introduced by using this formula to calculate surface area is no greater when applied to slightly spheroidal (i.e., biconvex) HS red cells than when applied to biconcave normal red cells.

The following expression then may be derived:

$\mathrm{Na}$ transport as mEq./ $/ \mu^{2}$ of surface area $\times \mathrm{hrs}$.

$$
=\frac{\left(\mathrm{k}_{\mathrm{ab}} \frac{1-\mathrm{H}}{\mathrm{H}}\right)\left([\mathrm{Na}]_{\text {pleams }}\right)(\mathrm{MCV})}{\left(10^{15}\right) \text { (Area) }} \text {. }
$$

Erythrocyte diameter was measured by the HadenHausser erythrocytometer ${ }^{7}$ with a reproducibility of $\pm 0.1 \mu$. The hematocrit figure employed to obtain $\mathrm{MCV}$ was the average true hematocrit of the experiment, and remained constant to within \pm 3 per cent (2 S.D.). Red cell counts as performed yielded the greatest source of possible error, being accurate only to within \pm 9 per cent (2 S.D.) as computed by the formula of Berkson, Magath, and Hurn (20). Obviously these errors could yield considerable variation in the rates calculated using Equation 5, but in practice the reproducibility was good (see Table I).

Determination of osmotic fragility (O.F.) and rate of autohemolysis $(A . H$.$) . The procedures used are described by$ Young and his associates $(21,22)$. The "50\% O.F." figure in Table $I$ is the concentration of sodium chloride solution in which 50 per cent of a cell population lyses after the cells have incubated for $24 \mathrm{hrs}$. at $37^{\circ} \mathrm{C}$. in autogenous serum. The figure for "A.H. at 48 hrs." is per cent hemolysis occurring in a cell population during $48 \mathrm{hrs}$. incubation at $37^{\circ} \mathrm{C}$. in autogenous serum.

\section{RESULTS}

The pertinent data are summarized in Table I. $\mathrm{Na}$ transport rates for normal erythrocytes (2.8 to $3.8 \mathrm{mEq}$. per L. cells $\times$ hrs.) (cases $\mathrm{A}, \mathrm{A}^{\prime}, \mathrm{B}$,

\footnotetext{
${ }^{7}$ Distributed by Clay-Adams, New York, New York.
}

$B^{\prime}, C$, and D) fit exactly with previously reported ranges $(10,11)$. Transport rates for the HS erythrocytes (cases 1 through 10) vary from high normal to considerably elevated figures. No advantage is gained in expressing $\mathrm{Na}$ transport in terms of surface area rather than volume: Both methods demonstrate equally well the difference between HS and normal red cells. Case histories, response to splenectomy, and the values reported here for cell thickness: diameter ratio, autohemolysis, and osmotic fragility leave no doubt that cases 1 through 10 correspond to the syndrome of hereditary spherocytosis; although patients 7,9 , and 10 have no similarly affected relatives, including both parents of each, among those tested.

Inspection of the data reveals no significant correlation between $\mathrm{Na}$ transport rates and total $\mathrm{Na}$ concentrations in cells, nor between $\mathrm{Na}$ transport rates and ratios of "rapidly exchangeable" $\mathrm{Na}$ : total $\mathrm{Na}$ concentrations in cells. The following scattergrams were constructed using the data from cases 1 through 10, but are not shown here:

$\mathrm{Na}$ transport rate versus plasma $\mathrm{Na}$ concentration;

$\mathrm{Na}$ transport rate versus osmotic fragility;

$\mathrm{Na}$ transport rate versus autohemolysis rate;

Total $\mathrm{Na}$ concentration in cells versus osmotic fragility;

Total $\mathrm{Na}$ concentration in cells versus autohemolysis rate;

Osmotic fragility versus autohemolysis rate;

Ratio of "rapidly exchangeable" $\mathrm{Na}$ : total $\mathrm{Na}$ concentration in cells versus osmotic fragility; Ratio of "rapidly exchangeable" $\mathrm{Na}$ : total $\mathrm{Na}$ concentration in cells versus autohemolysis rate.

None of these scattergrams revealed significant correlation; but it must be noted that the number of cases studied was small. In this laboratory (22), determinations on a much larger number of HS patients have demonstrated a positive correlation between osmotic fragility and rate of autohemolysis. HS erythrocytes cannot here be distinguished statistically from normal erythrocytes either in terms of total $\mathrm{Na}$ concentration or in terms of the "rapidly exchangeable" $\mathrm{Na}$ : total $\mathrm{Na}$ concentration ratio. Routine hematologic data (hemoglobin, hematocrit, and reticulocyte count) 


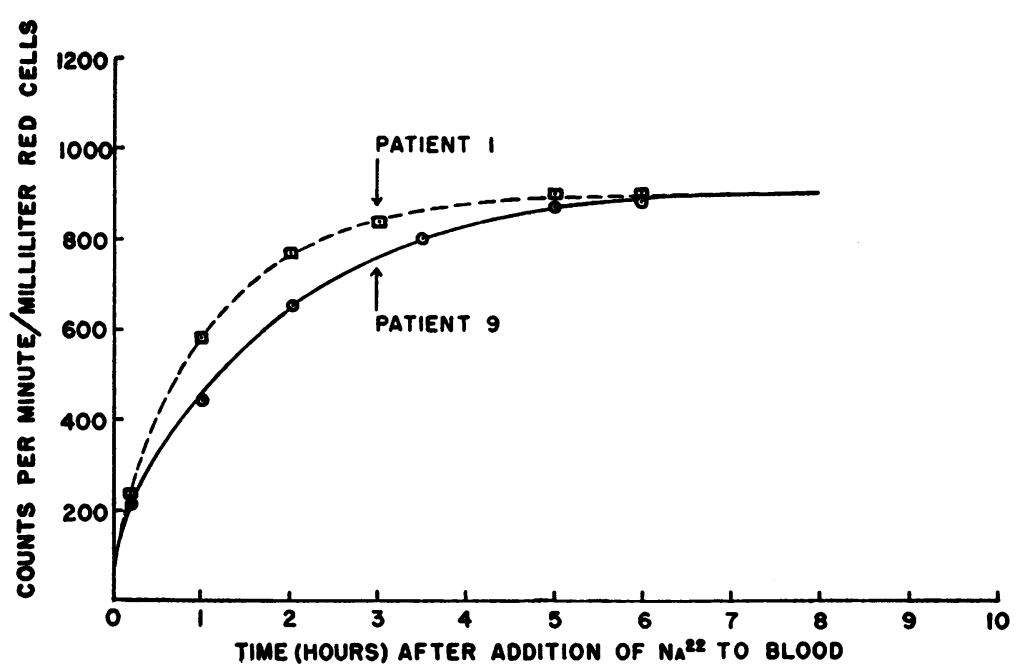

Fig. 1. In Vitro Rise of Radioactivity in Red Cells from Two HS Patients

These two patients represent opposite extremes of the scale of $\mathrm{Na}$ transport rate, patient 9 being at the upper limit of normal. The superimposition of plateaus is coincidental.

obtained before splenectomy were available on cases 4 through 10 ; no correlation exists between the apparent severity of the disease prior to splenectomy and the data reported here.

The average total initial $\mathrm{Na}$ concentration in cells, for the $10 \mathrm{HS}$ patients, is $8.1 \mathrm{mEq}$. per $\mathrm{L}$. cells; for the 6 determinations on the controls (cases A through D) the average concentration is 8.6. The average "rapidly exchangeable" $\mathrm{Na}$ concentration in cells for the $10 \mathrm{HS}$ patients is 6.8 ; for the 6 controls the figure is 6.6 . Combining these two sets of non-dissimilar averages one obtains an overall (16 determinations) average "slowly exchangeable" $\mathrm{Na}$ fraction of 19.3 per cent. Love and Burch's comparable figure (as calculated in [23]) is 17.8 per cent, and Gold and Solomon's figure (23) is 20.1 per cent.

\section{DISCUSSION}

There is satisfactory evidence that the defects of HS cells basically responsible for their shortened life span in the untreated (non-splenectomized) patient arise intrinsically (24). There is no evidence directly relating the known abnormalities of the HS cell to its premature in vivo destruction. The characteristically delayed passage of these spheroidal cells through the spleen of either a normal or an HS patient results in an ac- centuation of the cells' susceptibility to hypotonic hemolysis in vitro (25), but such low levels of tonicity are not realized in vivo. Selwyn and Dacie (26) have demonstrated that the hemolysis produced by the incubation of sterile HS blood is not attendant upon progressive erythrocyte swelling, and Crosby (27) cites evidence against the concept of hypotonic hemolysis being the result of "bursting" of the red cell from intracellular pressure.

The premature demise of the HS cell may be related to abnormal glycolysis $(2,3,28)$. There exists sufficient evidence $(2,3)$ to conclude that the incorporation of extracellular phosphate into ATP (adenosine triphosphate) in the HS red cell deviates significantly from normal. The present study indicates that the rate of transfer of $\mathrm{Na}$ across the HS cell surface membrane is higher by a variable amount than the rate across the membrane of the normal red cell; however, the total $\mathrm{Na}$ concentration (26, and this paper) of the HS cell is essentially normal. Transmembrane concentration gradients of both $\mathrm{Na}$ and $\mathrm{K}$ are reduced in the cold-stored normal erythrocyte (29), in HS or normal red cells incubated over $24 \mathrm{hrs}$. at $37^{\circ} \mathrm{C}$. (26), in sickled cells $(30,31)$, in red cells exposed to inhibitors of glycolysis (32), and in mammalian red cells exposed to a variety of nox- 
ious stimuli (33). Disordered phosphate turnover rates are not peculiar to the HS cell alone $(2,34)$, and it may well be that pathologically altered glycolytic pathways and abnormal cation transport rates (4) characterize erythrocytes destined for early destruction by a variety of forces (28). It is reasonable to imagine that specific enzyme defects or deficiencies in specific disease states might lead to this "final common pathway." A more general example of this is the aging normal erythrocyte, whose total enzyme activity level, it has been suggested (35), decreases exponentially with time. Pyruvic phosphoferase, required in the phosphorylation of ADP (adenosine diphosphate) to ATP, is activated by potassium ion, but the typically low $\mathrm{K}$ concentration of $\mathrm{HS}$ red cells probably does not contribute to their abnormal phosphate turnover (36).

The exact circumstances surrounding the early death of the HS cell in non-splenectomized patients are still not known. Selwyn and Dacie's work (26) showed that changes in $\mathrm{Na}$ concentration in $\mathrm{HS}$ cells during in vitro incubation at $37^{\circ} \mathrm{C}$. did not vary significantly from those occurring in normal human erythrocytes, even though incubation was carried out for 48 hours without added glucose. They suggested that "degenerative changes in the cell membranes" accounted for the increased rate of hemolysis of incubated HS cells, and linked this finding to prior speculation (37) on the role of the spleen in HS. The abnormal shape of the HS red cell certainly suggests a membrane defect, but further evidence exists: Prankerd, Altman, and Young found that the incorporation of radiophosphate into ATP and 2,3-diphosphoglycerate of the stroma of HS cells was lower than normal (2). Thus, a red cell membrane abnormality undoubtedly exists, but one must keep in mind that simplified mathematical analyses of isotope movement across cell surfaces, as in the present paper, are primitive approximations to probably complicated distributions involving total cell metabolism.

At present one cannot state with certainty how an accelerated movement of $\mathrm{Na}$ across the $\mathrm{HS}$ cell membrane is related to the aberrant behavior of these red cells in vivo and in vitro. The mechanism by which cations are transported across cell membranes is not known. Maizels has stated (6) that majority opinion favors "the view that $\mathrm{Na}$ and

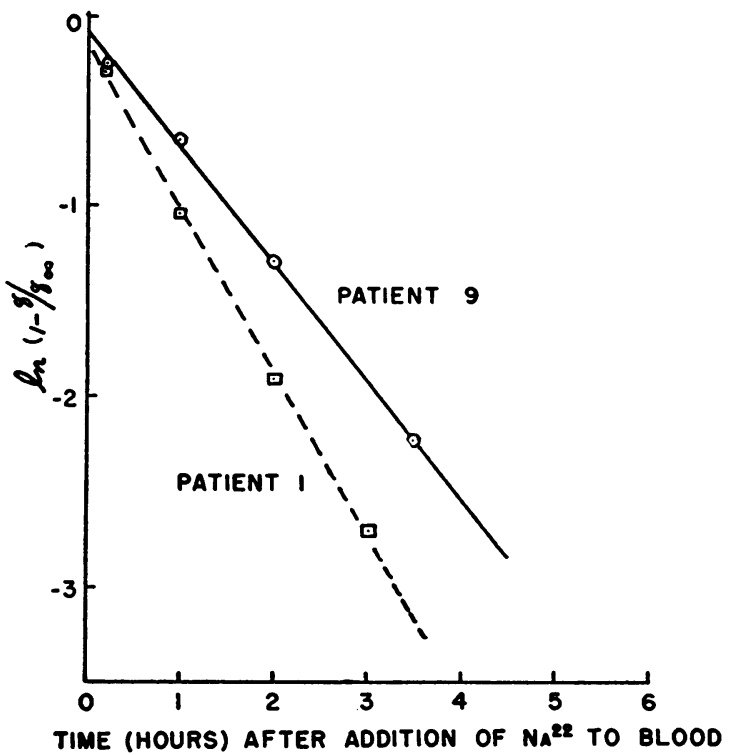

Fig. 2. Plot of the Logarithmic Function of q (Counts per Minute per Ml. of Red Cells) Against Time: The Two Patients are Those of Figure 1

The slopes $(T)$ of these plots employed in Equation 3 are actually calculated by the method of least squares from the original data. The plots are visual checks on the validity of the slope calculation. $\mathrm{q}_{\infty}$ represents counts per minute per ml. of red cells at plateau.

$\mathrm{K}$ are transported in complex combination with a carrier, presumably lipoid or lipoid soluble." There is evidence (38) that active fluxes of red cell $\mathrm{Na}$ and $\mathrm{K}$ are linked in some manner. Also, recent work by Glynn (39) indicates that, under certain circumstances, the movement of $\mathrm{Na}$ in vitro out of washed erythrocytes from normal humans may have a passive component not dependent on glycolysis. Should this passive $\mathrm{Na}$ flux exist also under the more physiologic experimental conditions of this paper, an accelerated passive efflux from HS cells could explain our findings. This explanation would also be consistent with the demonstration (26) that the rate of disappearance in vitro of glucose from serum containing HS cells is normal.

We chose splenectomized HS patients for the study presented in order that mean cell age might vary as little as possible from patient to patient. Harris and Prankerd (4) suggested that the younger cells in an erythrocyte population display a more active $\mathrm{Na}$ transport across their membranes. They also interpreted their data as sug- 
gesting that erythrocytes with high $\mathrm{Na}$ transport rates are more sensitive to hypotonic hemolysis: Our figures show no such correlation among the $10 \mathrm{HS}$ cell populations studied. Since studies on in vivo survival of red cells were not done on our patients, we cannot state with certainty that mean cell age was constant from experiment to experiment. Reports in the literature $(25,40)$ indicate that after splenectomy hereditary spherocytes have an essentially normal life span, although the conclusion is not unanimous (41). Furthermore, Harris and Prankerd (4) obtained a normal $\mathrm{Na}$ transport rate with the red cells of a patient with severe gastrointestinal bleeding and a reticulocyte count of 10 per cent. (In our series only case $\mathrm{D}$, a splenectomized normal control, had a reticulocyte count over 2 per cent.) Thus it seems that mean red cell age differences alone cannot account for the range of $\mathrm{Na}$ transport values in Table I.

Young has commented previously (42) on the absence of hematologic abnormality in both parents and all tested relatives of our cases 7, 9, and 10 (his patients WE, EH, and VO). Splenomegaly, anemia, reticulocytosis, and hyperbilirubinemia were absent, and determinations of osmotic fragility were normal. This suggested either a minor degree of penetrance in a carrier parent (assuming HS is inherited as a Mendelian dominant), or the possibility that the patients represented gene mutations. Our Table I indicates that the cells of cases 7,9, and 10 have the lowest transport constants of the HS group. Thus is strengthened the suspicion $(2,42)$ that the clinical syndrome of hereditary spherocytosis is a composite of genetically determined biochemical abnormalities in red cells, not all of which abnormalities need be present in one patient.

The values for total $\mathrm{Na}$ concentration in normal red cells are lower than some recently published $(16,23)$. The reason for this is not clear, since we too analyzed complete cell aliquots, not discarding the top Na-rich layer of cells. However, our figures serve chiefly to verify steady state conditions, and to provide comparative $\mathrm{Na}$ concentrations. Gold and Solomon (23) discovered that the red cells of two untreated (non-splenectomized) HS patients demonstrated a higher proportion than normal of "rapidly exchangeable" $\mathrm{Na}$, thereby suggesting "that the fraction of slowly exchanging $\mathrm{Na}$ may increase with the age of the red cell." The significance of slowly and rapidly exchanging $\mathrm{Na}$ fractions in red cells remains to be determined. Their existence is demonstrated experimentally by the ratio of $\mathrm{Na}$ specific activity in red cells to that in plasma, this ratio reaching a sub-unity value at plateau and remaining there at least to the $30-\mathrm{hr}$. point (23). Our work confirms this existence, but reveals no statistical difference $(\mathrm{P}>0.1)$ between normal red cells and postsplenectomy HS cells in regard to the magnitude of the fractions.

\section{SUMMARY}

1. In vitro $\mathrm{Na}$ transport rates were determined for the red cells of 10 splenectomized patients with hereditary spherocytosis (HS), and 4 normal controls. Osmotic fragility and rates of spontaneous autohemolysis were also determined on the red cells of these 14 individuals.

2. $\mathrm{Na}$ transport rates of $\mathrm{HS}$ cells ranged from high normal to considerably elevated values. The abnormal rates are consistent with the fact that glycolytic pathways deviate from normal in HS red cells; and erythrocyte cation transport is dependent on glycolysis. The possibility also exists that increased passive $\mathrm{Na}$ efflux, not linked to glycolysis, may be responsible for the abnormal rates.

3. $\mathrm{Na}$ transport rates of red cells of $3 \mathrm{HS} \mathrm{pa-}$ tients, each of whom had hematologically normal parents, were the lowest of the $10 \mathrm{HS}$ cases studied. This finding strengthens the suspicion that $\mathrm{HS}$ is a composite of genetically determined biochemical abnormalities.

4. The existence of slowly and rapidly exchanging $\mathrm{Na}$ fractions in red cells was confirmed. Normal red cells and post-splenectomy HS cells did not differ in regard to the magnitude of these fractions.

5. No significant correlations were found among $\mathrm{Na}$ transport rates, osmotic fragility, autohemolysis rates, total $\mathrm{Na}$ concentrations, and "rapidly exchangeable" $\mathrm{Na}$ concentrations of $\mathrm{HS}$ cells. Total $\mathrm{Na}$ concentrations and concentrations of "rapidly exchangeable" $\mathrm{Na}$ in $\mathrm{HS}$ cells were not distinguishable from the corresponding concentrations in normal erythrocytes.

6. Although experimental evidence indicates that the erythrocytes of HS patients have abnormally functioning surface membranes and altered intracellular glycolytic pathways, the precise mech- 
anisms leading to the shortened survival of these cells in non-splenectomized patients are not known.

\section{ACKNOWLEDGMENT}

Determinations of osmotic fragility, rate of autohemolysis, and red cell transverse diameter (by erythrocytometer) were performed by Miss Mary Jane Izzo. The author is grateful to Dr. Lawrence E. Young for access to this group of patients previously studied in this laboratory, and for his advice in the preparation of the manuscript.

\section{REFERENCES}

1. Young, L. E., Hereditary spherocytosis. Am. J. Med., 1955, 18, 486.

2. Prankerd, T. A. J., Altman, K. I., and Young, L. E., Abnormalities of carbohydrate metabolism of red cells in hereditary spherocytosis. J. Clin. Invest., 1955, 34, 1268.

3. Motulsky, A. G., Gabrio, B. W., Burkhardt, J., and Finch, C. A., Erythrocyte carbohydrate metabolism in hereditary hemolytic anemias. Am. J. Med., 1955, 19, 291.

4. Harris, E. J., and Prankerd, T. A. J., The rate of sodium extrusion from human erythrocytes. $\mathrm{J}$. Physiol., 1953, 121, 470.

5. Danielli, J. F., Morphological and molecular aspects of active transport. Symposia of the Society for Experimental Biology, Number 8: Active Transport and Secretion, New York, Academic Press, 1954, p. 502.

6. Maizels, M., Active cation transport in erythrocytes. Idem, p. 202.

7. Sheppard, C. W., and Martin, W. R., Cation exchange between cells and plasma of mammalian blood. I. Methods and application to potassium exchange in human blood. J. Gen. Physiol., 1950, 33, 703.

8. Raker, J. W., Taylor, I. M., Weller, J. M., and Hastings, A. B., Rate of potassium exchange of the human erythrocyte. J. Gen. Physiol., 1950, 33, 691.

9. Harris, E. J., and Maizels, M., The permeability of human erythrocytes to sodium. J. Physiol., 1951, 113, 506.

10. Solomon, A. K., The permeability of the human erythrocyte to sodium and potassium. J. Gen. Physiol., 1952, 36, 57.

11. Love, W. D., and Burch, G. E., In vitro studies of aspects of the metabolism of sodium by human erythrocytes using sodium". J. Lab. \& Clin. Med., 1953, 41, 337.

12. Bernstein, R. E., Rates of glycolysis in human red cells in relation to energy requirements for cation transport. Nature, 1953, 172, 911.

13. McGovern, J. J., Jones, A. R., and Steinberg, A. G., The hematocrit of capillary blood. New England J. Med., 1955, 253, 308.

14. Furth, F. W., Effect of spherocytosis on volume of trapped plasma in red cell column of capillary and
Wintrobe hematocrits. J. Lab. \& Clin. Med., 1956, 48, 421.

15. Berry, J. W., Chappell, D. G., and Barnes, R. B., Improved method of flame photometry. Indust. \& Engin. Chem. (Anal. Ed.), 1946, 18, 19.

16. Keitel, H. G., Berman, H., Jones, J., and MacLachlan, $E$., The chemical composition of normal human red blood cells, including variability among centrifuged cells. Blood, 1955, 10, 370.

17. Clarkson, E. M., and Maizels, M., Sodium transfer in human and chicken erythrocytes. J. Physiol., 1955, 129, 476.

18. Love, W. D., and Burch, G. E., Plasma and erythrocyte sodium and potassium concentrations in a group of southern white and negro blood donors. J. Lab. \& Clin. Med., 1953, 41, 258.

19. Ponder, E., Hemolysis and Related Phenomena. New York, Grune \& Stratton, 1948, p. 24.

20. Berkson, J., Magath, T. B., and Hurn, M., The error of estimate of the blood cell count as made with the hemocytometer. Am. J. Physiol., 1940, 128, 309.

21. Young, L. E., Izzo, M. J., and Platzer, R. F., Hereditary spherocytosis. I. Clinical, hematologic and genetic features in 28 cases, with particular reference to the osmotic and mechanical fragility of incubated erythrocytes. Blood, 1951, 6, 1073.

22. Young, L. E., Izzo, M. J., Altman, K. I., and Swisher, S. N., Studies on spontaneous in vitro autohemolysis in hemolytic disorders. Blood, 1956, 11, 977.

23. Gold, G. L., and Solomon, A. K., The transport of sodium into human erythrocytes in vivo. J. Gen. Physiol., 1955, 38, 389.

24. Dacie, J. V., The Haemolytic Anaemias Congenital and Acquired. London, J. \& A. Churchill, Ltd., 1954.

25. Emerson, C. P., Jr., Shen, S. C., Ham, T. H., Fleming, E. M., and Castle, W. B., Studies on the destruction of red blood cells. IX. Quantitative methods for determining the osmotic and mechanical fragility of red cells in the peripheral blood and splenic pulp; the mechanism of increased hemolysis in hereditary spherocytosis (congenital hemolytic jaundice) as related to the functions of the spleen. Arch. Int. Med., 1956, 97, 1.

26. Selwyn, J. G., and Dacie, J. V., Autohemolysis and other changes resulting from the incubation in vitro of red cells from patients with congenital hemolytic anemia. Blood, 1954, 9, 414.

27. Crosby, W. H., The pathogenesis of spherocytes and leptocytes (target cells). Blood, 1952, 7, 261.

28. Prankerd, T. A. J., The metabolism of the human erythrocyte: A review. Brit. J. Haemat., 1955, 1, 131.

29. Gabrio, B. W., and Finch, C. A., Erythrocyte preservation. I. The relation of the storage lesion to in vivo erythrocyte senescence. J. Clin. Invest., 1954, 33, 242.

30. Tosteson, D. C., Carlsen, E., and Dunham, E. T., 
The effects of sickling on ion transport. I. Effect of sickling on potassium transport. J. Gen. Physiol., 1955, 39, 31.

31. Tosteson, D. C., The effects of sickling on ion transport. II. The effect of sickling on sodium and cesium transport. J. Gen. Physiol., 1955, 39, 55.

32. Love, W. D., Cronvich, J. A., and Burch, G. E., Mechanisms controlling cation concentrations in the human cell : Evidence from the effect of iodoacetate on $\mathrm{Na}$ and $\mathrm{K}$ exchange rates of the erythrocyte. J. Clin. Invest., 1955, 34, 61.

33. Green, J. W., The separation of cation exchange and glycolysis in human red cells exposed to nonionizing radiations. J. Cell. \& Comp. Physiol., 1956, 47, 125.

34. Prankerd, T. A. J., The uptake of radioactive phosphate and its distribution amongst esters in sickled cells. Clin. Sc., 1955, 14, 381.

35. Allison, A. C., and Burn, G. P., Enzyme activity as a function of age in the human erythrocyte. Brit. J. Haemat., 1955, 1, 291.

36. Prankerd, T. A. J., The effect of intracellular $\mathrm{K}$ on red cell metabolism. Clin. Sc., 1955, 14, 633.
37. Ham, T. H., and Castle, W. B., Relation of increased hypotonic fragility and of erythrostasis to the mechanism of hemolysis in certain anemias. $\mathrm{Tr}$. A. Am. Physicians, 1940, 55, 127.

38. Harris, E. J., Linkage of sodium- and potassiumactive transport in human erythrocytes. Symposia of the Society for Experimental Biology, Number 8: Active Transport and Secretion. New York, Academic Press, 1954, p. 228.

39. Glynn, I. M., Sodium and potassium movements in human red cells. J. Physiol., 1956, 134, 278.

40. Schrumpf, C. A. A., Role of the spleen in familial spherocytosis. Proceedings of the Third International Congress of the International Society of Hematology, Cambridge, 1950, New York, Grune \& Stratton, 1951, p. 94.

41. Motulsky, A. G., Giblett, E., Coleman, D., Gabrio, B., and Finch, C. A., Life span, glucose metabolism and osmotic fragility of erythrocytes in hereditary spherocytosis. J. Clin. Invest., 1955, 34, 911.

42. Young, L. E., Observations on inheritance and heterogeneity of chronic spherocytosis. Tr. A. Am. Physicians, 1955, 68, 141. 